\title{
Online Forums as a Mirror Reflecting the World of ESP
}

\author{
Agnieszka Dzięcioł-Pędich \\ School of Foreign Languages, University of Białystok \\ Correspondence concerning this article should be addressed to Agnieszka Dzięcioł-Pędich, University of \\ Bialystok, ul. M. Skłodowskiej-Curie 14, Białystok, Poland, 15-097. E-mail: lumriel@gmail.com
}

\begin{abstract}
The article presents the analysis of most frequent ${ }^{1}$ threads in four Internet forums to see what can be learnt about ESP teachers' interests and understanding of the concept of English for Specific Purposes (ESP). The results show that the majority of discussions revolve around the choice of materials for different types of ESP. This might suggest that forum members know very little about oral and written communicative strategies of a given profession and rely on the expertise of course books writers to provide them with such knowledge. Moreover, the analysis shows that forum members do not discuss how to teach individual language skills but how to teach different types of ESP which might indicate that there is a greater difference between teaching the same skills in two branches of ESP than there is between teaching different skills with a single type of ESP. The results also indicate that some users feel that ESP teachers should be interested in more than just linguistics, but there are those who claim that the main difference between ESP and general English lies in vocabulary. This polarity of opinions shows that no established view of ESP may exist. The analysis further suggests that the distinction between ESP and EGP is clearer to those who are more interested in learners' professional needs. Finally, the choice of topics in the analysed threads indicates that forum members and their visitors are interested not only in ESP, but in subjects which have nothing to do with ESP.
\end{abstract}

Keywords: ESP, online forum, online community, trends, materials

Literature devoted to English for Specific Purposes (ESP) shows what methodology can be applied to teaching different professionals, what the teacher's and learners' roles are, how to conduct needs analysis and syllabus design and what materials to use. These are general guidelines but each teaching situation is different and might require a more detailed approach. Consequently, ESP teachers are likely to look for teaching tips and techniques among the teaching community who might share similar experiences.

Nowadays teaching communities can be found not only in schools or other educational institutions but also in online forums which are asynchronous computer mediated communication in an online space, which usually revolves around more than one

\footnotetext{
${ }^{1}$ Every time a forum thread is viewed by anyone, this fact is recorded by the forum database and the number of views is usually displayed next to the thread title in forum contents.
}

topic and connects people through written messages (Santosa et al., 2005 in Kanur, 2011; Cyprus, 2016).

Participating in online discussions, teachers acquire new ideas and perspectives, refine old ones, learn about employment opportunities and establish professional contacts (Pavlina, 2005). Furthermore, teachers have instant access to knowledge which would otherwise have to be purchased (Chindeu, 2008), for example, in the form of a book. It should be stressed that teachers who turn to online forums might not always find an answer to their question but they will probably observe that others face a similar difficulty assuring them that their problems are not a sign of their incompetence. Thanks to the opportunity of being anonymous, teachers enjoy a greater degree of confidence in expressing their point of view, answer questions, especially controversial ones, more honestly or share intimate knowledge about themselves or other people (Amir, 2012). 


\section{Materials and Methods}

\section{Research Description}

Internet forums offer insight into the interactions of this community and the analysis of forum posts and thread views can help answer at least some kinds of practical questions about needs and interests of ESP teachers. Moreover, they show how teachers teach needs-related English and how they understand the concept of ESP which has been widely debated in academic literature (Smoak, 2003). Therefore, the research was motivated by the following questions:

1. What are the common issues in the ten most frequently viewed threads in the analysed forums and what do they reveal about the needs of the teaching community?

2. How do forum users understand the concept of English for Specific Purposes (ESP), especially business English?

The forums were found through a Google search using the search term forums for business English teachers. Interestingly, results for this search term resulted in four forums devoted to business English and other types of ESP while the search terms forums for ESP teachers, ESP teachers forums, teaching ESP forum brought websites with a much more general scope. Similarly, search terms focusing on other varieties of ESP such as medical English teachers forum, legal English teachers forum, technical English teachers forum resulted in links to general ESL websites and forums or single threads in these general forums. Therefore, the search term forums for business English teachers turned out to be the most useful for this paper. The forums analysed in this paper were the first, fifth, sixth and fifteenth search result for this term. The remaining high-ranking search results were not applicable to this study because they were either online forums which contained too few posts devoted to the subject in question or articles and websites containing the search term. For example, one of the results was a link to http://www.tefl.net/forums/index.php which is an index of forums devoted to various aspects connected with teaching English for general Purposes; another result was a link to a Polish forum for business English teachers where one can mainly find advertisements of language teachers giving private business English lessons; yet another result was a link to an article in the Guardian newspaper on the professionalism of the ESP teaching community; etc. Only organic search results were considered, i.e. advertisements and sponsored links were not included (Blake, 2006). These were the links from the first two search result pages and the question is how likely ESP teachers might be to browse more than the first two pages of Google search results. From each forum, ten threads were selected for a closer analysis based on their number of views. Table 1 shows the most frequently viewed threads in the analysed forums. It is assumed that these threads which were viewed by the largest number of visitors might be the ones which are of the greatest interest to the users of these forums (presumably representing the ESP community). While this may not necessarily be true in all case, there is no better statistic to be used for selecting threads. Posts in the treads as shown in Table 1 were analysed for common topics.

The following forums for teachers of ESP were analysed for the purposes of the research:

- Forum 1 is available at: http://www.tefl.net/ forums/viewforum.php? $\mathrm{f}=15 \&$ sid=e $63531 \mathrm{a} 0$ bc9cee1323fab68e7c86163f. The forum was accessed on 13.06. 2016 and at that time it had 31 threads. The oldest post dates back to 2004 and the forum is still active

- Forum 2 is available at: http://forums.eslcafe. com/teacher/viewforum.php?f $=6$. The forum was accessed on 13.06. 2016 and at that time it had 601 threads. The oldest post dates back to 2003 and the newest ones come form 2009, but since then no new post have been added. However, the forum is still visited. For instance on 13.06. 2016 the thread "How to handle awkward teaching situation" had a total of 8569 views and on 20.06.2016 it had 8581 views.

- Forum 3 is available at: http://www.esl-jobsforum.com/viewforum.php?f=16. The forum was accessed on 14.06.2016 at that time it had 15 threads. The oldest post dates back to 2005 and the forum is still active.

- Forum 4 is available at: http://www. onestopenglish.com/english-for-specificpurposes/13.forum . The forum was accessed on 17.06.2016 and at that time it had 14 threads. The oldest post dates back to 2009 and the newest one is from January 2016. Contrary to previous three forums, this one does not list the number of views for individual threads but only for the whole forum.

\section{Results and Discussion}

\section{Thread Views}

The number of thread views has shown that Forum 1 and Forum 3 are much more frequently visited than Forum 2 and 4. Moreover, as shown in Table 1, threads in the first three forums were viewed by a large number of users, but there were only a few posts in each of the analysed threads in all forums, and only a small number of users were involved in the discussion. The reason for that might be the abundance of social media sites 
Table 1

The most frequently viewed threads

\begin{tabular}{|c|c|c|c|c|c|c|c|c|c|c|c|}
\hline \multicolumn{3}{|c|}{ Forum 1} & \multicolumn{3}{|c|}{ Forum 2} & \multicolumn{3}{|c|}{ Forum 3} & \multicolumn{3}{|c|}{ Forum 4} \\
\hline Thread & Views & Posts & Thread & Views & Posts & Thread & Views & Posts & Thread & Views & Posts \\
\hline $\begin{array}{l}\text { Teaching Eng- } \\
\text { lish for science, } \\
\text { tourism, IT, } \\
\text { maths }\end{array}$ & 17887 & 7 & $\begin{array}{l}\text { How to handle } \\
\text { awkward teach- } \\
\text { ing situation }\end{array}$ & 8569 & 11 & $\begin{array}{l}\text { Familiarising } \\
\text { oneself with the } \\
\text { business world }\end{array}$ & 18439 & 8 & $\begin{array}{l}\text { English for } \\
\text { Sales and Retail } \\
\text { - coursebook }\end{array}$ & - & 2 \\
\hline $\begin{array}{l}\text { Making busi- } \\
\text { ness letters fun }\end{array}$ & 13237 & 4 & $\begin{array}{l}\text { Hello, and what } \\
\text { is business } \\
\text { English? }\end{array}$ & 7823 & 11 & First time with & 17542 & 6 & $\begin{array}{l}\text { English for } \\
\text { graduates in } \\
\text { Transport and } \\
\text { Logistics }\end{array}$ & - & 1 \\
\hline $\begin{array}{l}\text { Activities/ } \\
\text { conversation } \\
\text { to promote } \\
\text { English }\end{array}$ & 11350 & 3 & $\begin{array}{l}\text { Business Eng- } \\
\text { lish writing }\end{array}$ & 7039 & 6 & $\begin{array}{l}\text { Business } \\
\text { teaching } \\
\text { methodologies }\end{array}$ & 13932 & 6 & $\begin{array}{l}\text { Teaching } \\
\text { English to res- } \\
\text { taurant staff }\end{array}$ & - & 2 \\
\hline $\begin{array}{l}\text { Pay scale } \\
\text { for business } \\
\text { English }\end{array}$ & 11823 & 7 & $\begin{array}{l}\text { Business } \\
\text { English for IT } \\
\text { professionals }\end{array}$ & 6704 & 10 & $\begin{array}{l}\text { SwinGuru: } \\
\text { antispam guide } \\
\text { :) } 0001\end{array}$ & 11473 & 1 & $\begin{array}{l}\text { Need for mate- } \\
\text { rials for indus- } \\
\text { try English }\end{array}$ & - & 1 \\
\hline $\begin{array}{l}\text { Help: Busi- } \\
\text { ness English } \\
\text { textbooks }\end{array}$ & 11508 & 5 & $\begin{array}{l}\text { Business and } \\
\text { ESP conversa- } \\
\text { tion materials }\end{array}$ & 6464 & 8 & $\begin{array}{l}\text { Selling yourself } \\
\text { to Businesses... }\end{array}$ & 11309 & 2 & $\begin{array}{l}\text { ESP for build- } \\
\text { ers? }{ }^{* * *} \mathrm{HELP}^{* * *} ! !\end{array}$ & - & 1 \\
\hline $\begin{array}{l}\text { Crossing the } \\
\text { language } \\
\text { barrier }\end{array}$ & 11148 & 3 & $\begin{array}{l}\text { TOEIC prepara- } \\
\text { tion courses }\end{array}$ & 5230 & 2 & $\begin{array}{l}\text { What antivirus } \\
\text { do you use? }\end{array}$ & 10919 & 5 & $\begin{array}{l}\text { Aviation } \\
\text { English }\end{array}$ & - & 1 \\
\hline $\begin{array}{l}\text { Successful } \\
\text { communication }\end{array}$ & 10456 & 3 & $\begin{array}{l}\text { Business } \\
\text { English One- } \\
\text { to-One ... any } \\
\text { tips? }\end{array}$ & 4861 & 6 & $\begin{array}{l}\text { Information on } \\
\text { teaching ESL } \\
\text { business classes }\end{array}$ & 8950 & 3 & $\begin{array}{l}\text { Teaching Eng- } \\
\text { lish for Hotel } \\
\text { Personnel }\end{array}$ & - & 3 \\
\hline Teaching pilots & 10219 & 4 & $\begin{array}{l}\text { (POLL) teach- } \\
\text { ing by tele- } \\
\text { phone (Skype) }\end{array}$ & 4159 & 3 & $\begin{array}{l}\text { Need verifi- } \\
\text { cation - Has } \\
\text { anyone heard of } \\
\text { Comunicorp? }\end{array}$ & 8540 & 1 & $\begin{array}{l}\text { Selling in Eng- } \\
\text { lish - can you } \\
\text { recommend any } \\
\text { materials }\end{array}$ & - & 1 \\
\hline $\begin{array}{l}\text { Technical Eng- } \\
\text { lish Books }\end{array}$ & 7736 & 5 & $\begin{array}{l}\text { Distance DELTA } \\
\text { - pre-course } \\
\text { reading - any } \\
\text { suggestions }\end{array}$ & 4027 & 3 & $\begin{array}{l}\text { Just wanted to } \\
\text { say Hello }\end{array}$ & 7460 & 1 & $\begin{array}{l}\text { Trends } \\
\text { materials }\end{array}$ & - & 1 \\
\hline $\begin{array}{l}\text { The LCCI Foun- } \\
\text { dation Certifi- } \\
\text { cate in Business } \\
\text { English }\end{array}$ & 7607 & 3 & $\begin{array}{l}\text { Business Eng- } \\
\text { lish Curriculum } \\
\text { for Consulting }\end{array}$ & 3742 & 2 & $\begin{array}{l}\text { Ould Kad- } \\
\text { dour BRC : } \\
\text { British Rally } \\
\text { Championship }\end{array}$ & 6403 & & $\begin{array}{l}\text { Teaching } \\
\text { English to an } \\
\text { accountant }\end{array}$ & - & 4 \\
\hline
\end{tabular}

which has reduced the amount of time people spend per session in forums (Sabnani, 2012)). Furthermore, it is known that so-called user-generated content is only created by a small percentage of users. As Arthur (2006) observes: "It's an emerging rule of thumb that suggests that if you get a group of 100 people online then one will create content, 10 will 'interact' with it (commenting or offering improvements) and the other 89 will just view it". There are also technical reasons why there are always more views of a thread than posts in it - a single user may visit a thread multiple times, users may revisit a thread as new post appear, etc. Nevertheless, the disproportion between the number of posts and the number of views is strikingly high.

As shown in Table 1 all forums contain threads the names of which suggest that their content might be related to different types of ESP such as English for
IT, Aviation English or English for Accountancy. The fact that four different forums contain such threads and the number of views of these threads suggests that content tailored for work-related needs of various professions is in great demand.

It is worth considering what a high number of views of such threads might mean. In the first place teachers might be looking for an answer on how a given type of ESP is commonly understood and therefore how a syllabus for this type of ESP should be designed. Secondly, they may be searching for profession-related classroom materials and/or sources of such teaching aids. They could also want to get new teaching tips or brush up on old ones.

Common topics in such threads confirm these assumptions. In Forum 1, in the thread Teaching English for science, tourism, IT, Maths, a forum member asked 
how to teach $12^{\text {th }}$ grade students, who were focusing on such careers as science, tourism, maths, and computer science, to communicate more effectively in their future professions. In the same forum, in the thread Teaching pilots, a person asked for help in choosing a book for pre-intermediate learners of Aviation English. In Forum 2, in the thread Business English for IT professionals, a forum member asked about websites where he could purchase supplementary materials for a language course for IT industry. In the same forum, in the thread Business English Curriculum for Consulting, a person who was developing a business English curriculum with emphasis on consulting services was searching for a place where he could obtain curriculum packages including books, manuals, activities, and visual aids. In Forum 3, in the thread Information on teaching ESL business classes, a person would like to receive information about tips for teaching intermediate adults who learn business English and on links to websites where such advice could be found. Furthermore, he wondered how teaching business English is different from teaching general English. In Forum 4 nine of the ten analysed threads are related to different types of ESP. For instance, in the thread English for graduates in Transport and Logistics a forum member was looking for examples of professional documents related to the field. In the thread Selling in English - can you recommend material? a person was searching for materials he could use during a workshop with sales people.

Another common issue, as suggested by the names of threads in Forum 1 and Forum 2, is course materials and textbooks. This indicates that ESP teachers are constantly looking for appropriate texts and other teaching aids which could mean that the publishing market does not offer the resources teachers need. Discussions about textbooks show that teachers struggle to choose the best course books for their learners or at least need advice choosing. In Forum 1, in the thread Help: Business English Textbooks, a person asked other forum members to recommend good textbooks, because a catalogue from one of the publishers was not much help. In the same forum, in the thread Technical English Books, a forum member was trying to find graded books for learners of technical English. However, in Forum 2, in the thread Business and ESP conversation materials, a person was promoting conversation and speaking materials she has created. It should be stressed, however, that the issue of materials appears in other threads as well, even though the name may not suggest that. In Forum 3 the issue of course books appeared in the thread Familiarising oneself with the business world where forum users recommended books and websites which might be useful for teachers who are new to ESP. In Forum 4 all the analysed threads contained requests for advice on the choice of ESP materials or on how to adapt them to learners' needs. For instance, in the thread Teaching English to an accountant a forum member asked how to adapt English for accounting course books for a pre-intermediate level learner. Interestingly, one of the pieces of advice he received was to use realia, such as bank statements.

Analysis of the threads has also revealed that writing is the only language skill discussed in the top ten threads (according to the number of views) in Forum 1 and Forum 2. This might be an indication that writing is considered to be the most problematic skill to develop during ESP courses. The analysis of posts in these forums shows that in Forum 1, in the thread Making business letters fun, the user would like to know how to make writing letters a fun activity and in Forum 2, in the thread Business English Writing, the user was trying to create a collection of Business English lessons for all language levels with emphasis on writing and was asking about books she could buy or websites where she could find the necessary materials.

The last common subject that appeared in Forum 1 and Forum 2 was language certificates. Users looked for information on certificates which they could use to raise their qualifications. For instance, in Forum 1, in the thread the LCCI Foundation Certificate in Business English, the user was looking for information about the certificate because she would like to offer Business English courses and earn a better salary. Forum users were also interested in certificates which would be most appropriate for their learners. In Forum 2, in the thread TOEIC preparation courses, the user needed information on TOEIC preparation courses which they could use with business administration students.

Finally, In Forum 2 and Forum 4 there were threads where members ask for materials or advice on how to conduct one-to-one lessons. For example, in Forum 2, in the thread Business English One-to-One ... any tips?, a forum member was asking how to approach 3-hours sessions with an Italian businessman who wants to study business English and grammar. In Forum 4, in the thread English for Sales and Retail coursebook?, a forum member was searching for advice on how to conduct private one-to-one lessons for French students working in retail selling jewellery and accessories.

\section{The Concept of English for Specific Purposes}

The second research question concerned ESP teachers' understanding of the concept of English for Specific Purposes. The data showed that the most frequently viewed thread in Forum 3 was Familiarising oneself with the business world, which offered interesting insight into what teachers who were new to ESP want to know about ESP teaching methodology and what 
advice those who had already been working in the field could offer. The user who started this thread wanted to know what it meant to acquire the knowledge of the business world. He also wanted to know what, apart from picking his students' brains, he could do to gain such knowledge. For that reason, he asked about easily 'digestible' trade magazines or newspapers. Other forum members recommended joining an institution similar to the Chamber of Commerce, subscribing to business newsletters, reading the business pages of a quality daily newspaper, watching business reports on $\mathrm{TV}$, or working with such course books as Intelligent Business or Teaching Business English and a website: http://www.breakingnewsenglish.com/. The user was also advised to conduct needs analysis to learn their students' language levels and was shown some basic ways of doing so. Moreover, he was warned not to introduce complex business issues to students who are beginners. Interestingly, one of the forum members observed that the more one knows about business, the more credibility one has with the learners but it takes time and effort to build one's knowledge base. On the other hand, another forum member claimed he teaches only general English with emphasis on transactional language, i.e. language which would help different professions in oral communicative exchanges related to their field. The main conclusion which can be drawn from the comments in this thread is that teaching business English requires more than just knowledge of the language.

The conviction that teaching business English differs from teaching general English was visible in the third most popular thread in the same forum - Business teaching methodologies. The person who started the discussion asked what different styles of teaching business English there are and whether there are some teaching methodologies that are better than others. One of the commentators observed that there is a teaching methodology called SQRRR where S stands for Survey, $\mathrm{Q}$ for Question, $\mathrm{R}$ for Read, $\mathrm{R}$ for Recollect and $\mathrm{R}$ for Remember. Another person observed that business English teaching is more specialized, especially in the area of vocabulary. Yet another commentator argued that English classes do not develop business English effectively and recommended such software as Espoir Smart English through Management Ideas' for Managers \& CEOs, which is supposed to teach usable English, boost one's thinking and knowledge of the business and corporate world, as well as develop soft skills. Interestingly, in his opinion, there is almost no difference between business English or social English, but each speaker might need different terminology and might have different expectations.

Almost all the posts in this thread indicate the need for special preparation for teaching business English, but they do not explain the role of the business
English teacher. Some comments on the teachers role appeared in the thread First time with... . One of the users observed that one should be a 'facilitator' rather than a 'teacher' and that the role of a business English teacher is to help learners communicate in English rather than to teach them in the traditional sense. She further argued that the teacher has to respect their learners' expertise.

A discussion about the nature of business English can also be found in the thread Hello, and what is business English? in Forum 2. The person who started the discussion wanted to know if business English is simply a jargon used in the business world and whether there is common 'business English' across various professions. According to the first answer in the thread, business English means teaching English for use in a business setting, regardless of how this setting is defined. In another post, we can read that Business English means different things to different people. Moreover, the author of this posts suggested that business English might be a clever marketing ploy. The authors of other posts claimed that there are topics and registers which are more appropriate to business situations, writing conventions that are more likely to be used only in business contexts, or some stylistic considerations, but a person needs to master grammar and simple spoken English, otherwise she or he will not be able to master any type of ESP. They also argued that business English might involve a significant amount of jargon but learners need elements of general English as well. As far as teaching methodology is concerned, we can read that it is worth combining students' business experience with one's own teaching experience and compare them to the scenarios form course books. In one of the last posts in the thread the author stressed that the teacher needs more than pages from course books to teach ESP effectively, as they will not hold up under the scrutiny of their learners who are experts in their fields. Consequently, depending on the type of ESP teachers teach, they should know, for instance, basic differences between legal systems from different countries or different ways of doing business across cultures.

The discussion about the nature of business English can also be found in Forum 1, but not among the top ten most frequently viewed threads. In the thread Does Business English Really exist? the author of the thread claimed that business English does not exist. The only thing that is real, in his opinion, is business vocabulary and some set phrases. He wanted to know whether there is Business Grammar or Business Phonetics. In the thread Why bother teaching Business English? the first user to answer argued that, apart from the fact that 'academic writing' is characterized by a higher percentage of passive voice structures as compared to other types of English, there are no other significant 
differences among English 'types', regardless of the content area. One of the participants of the discussion observed that there is a difference between a CELTA and ESP approach to teaching which stems from the fact that ESP courses are oriented around specific needs of the learners. Yet another user thought that teaching Business English can be really demanding, especially when the teacher is expected to help their learners with profession specific jargon which is frequently too technical. In one of the final posts in the thread we can read that it is vocabulary and functions that might be the source of differences between English for Specific Purposes and English for General Purposes but regardless of the type of ESP people learn they also need general English.

In the top ten most frequently viewed threads, more specifically in the thread Pay scale for business English, forum users discussed salaries of ESP teachers in different countries. This discussion seemed to suggest that another difference between ESP and EGP lies in the amount of money teachers receive. The statement that ESP teachers are likely to be paid more would need to be confirmed by a different research project.

\section{Conclusion}

The analysis of threads in the forums shows that the majority of discussions revolve around the choice of materials, even though the name of the thread may not indicate that, for different types of ESP. In the first place forum members ask about existing course books. This gives rise to the question whether the course book defines the methodology, or the methodology influences the selection (Sharma, 2011). This might also suggest that forum members know very little about oral and written communicative strategies of a given profession and rely on the expertise of course books writers to provide them with such knowledge. In the second place forum users search for ready teaching packages and websites which offer access to ESP materials. No one advises anyone to design their own materials from scratch and there are only a few remarks concerning the use of authentic documents. Does it mean that teachers do not feel qualified enough to design specialist materials, or that it is too time consuming, or that it is simply not what people are looking for in forums?

The discussion of the nature of ESP is not unanimous. On the one hand, there are forum members who see that ESP is different from EGP and who feel that ESP teachers should be interested in more than just linguistics. On the other hand, there are those who claim that the main difference between ESP and EGP lies in vocabulary and in the end all we do is teach plain old general English. This polarity of opinions shows that no established view of ESP may exist. The analysis further suggests that the distinction between ESP and EGP is clearer to those who are more interested in learners' professional needs.

Interestingly, forum members do not discuss, at least in the analysed threads, how to teach individual language skills but how to teach different types of ESP. Only threads concerning teaching writing appeared in two of the analysed forums which indicates that there is a greater difference between teaching the same skills in two branches of ESP than there is between teaching different skills with a single type of ESP. In other words, different skills within one branch of ESP have more in common with each other than the same skills with various branches of ESP. Furthermore, teaching individual skills might be connected more to the area of expertise of EGP, as teachers (because of their training) already know how to do that.

The analysis of posts suggests that most forum members are employed by companies and language schools, rather than higher education institutions, which gives rise to the question to what extent the advice which can be found in such forums is applicable to tertiary language courses.

Finally, the choice of topics in the analysed threads and in the forums in general indicates that forum members and their visitors are interested not only in ESP, but also in other subjects, including some which have nothing to do with ESP. This shows that internet forums may not only be a platform for sharing information, but also a meeting place for the community.

\section{References}

Amir, R. (2012). What is the purpose of anonymity? Retrieved June 16, 2016 from https://www.quora. $\mathrm{com} /$ What-is-the-purpose-of-anonymity

Arthur, C. (2006). What is the $1 \%$ rule? The Guardian. Retrieved June 17, 2016 from https://www. theguardian.com/technology/2006/jul/20/ guardianweeklytechnologysection2

Blake (2006, July 6). Why not in the free search results? [Blog post]. Retrieved from https://adwords. googleblog.com/2006/07/why-not-in-free-searchresults.html

Chinedu, E. (2008). Seven benefits of Internet forums. Ezine Articles. Retrieved June 16, 2016 from http:// ezinearticles.com/?Seven-Benefits-of-InternetForums\&id $=1813184$

Cyprus, S. (2010). What is an Internet forum? Retrieved March 5, 2016 from http://www.wisegeek.com/ what-is-an-internet-forum.htm 
Kanur, M. (2011). Using online forums in language learning and education. Student Pulse, 3(3). Retrieved March 5, 2016 from http://www. studentpulse.com/articles/414/using-onlineforums-in-language-learning-and-education

Pavlina, S. (2005). Effective online forum usage. Retrieved June 8, 2016 from http://www.stevepavlina.com/ articles/effective-online-forum-usage.html

Sabnani, S. (2012, March 15). Are Internet forums dead? [Answer 1]. Answer posted to https://www.quora.
com/Are-internet-forums-dead

Sharma, P. (2011). Controversies in business English. Retrieved June 20, 2016 from https://www. teachingenglish.org.uk/article/controversiesbusiness-english

Silberman, G. (2012). What is the purpose of anonymity? Retrieved June, 82016 from https://www.quora. $\mathrm{com} /$ What-is-the-purpose-of-anonymity

Smoak, R. (2003). What is English for specific purposes? Forum, 41(2), 22-27. 